\title{
Migrações e processos socioespaciais no Eixo Pelourinho-Santo Antônio. Salvador, Bahia
}

\author{
Migrations and sociospatial processes \\ in the Pelourinho-Santo Antônio Axis, Salvador, State of Bahia
}

Daniel de Albuquerque Ribeiro [I]

\begin{abstract}
Resumo
Este artigo tem por objetivo elucidar as relações entre os processos espaciais urbanos e as migrações em uma área da cidade de Salvador, que denominamos Eixo Pelourinho-Santo Antônio (EPS). Neste, buscou-se demonstrar que os diferentes processos espaciais urbanos, que geralmente são retratados em esquemas fechados na própria cidade, podem ser observados em uma escala mundial. Para isso, realizaram-se estudos sobre migrações em Salvador - Bahia, relacionando-os com os processos socioespaciais urbanos da cidade, desde sua fundação até a contemporaneidade. Constatou-se que o EPS constitui, desde a origem da cidade, um polo receptor de imigrantes. No avançar do tempo, novos fluxos foram se configurando entre Salvador e o mundo, gerando, na área estudada, um complexo mosaico populacional com contribuições étnicas de todos os continentes.
\end{abstract}

Palavras-chave: migrações; processos socioespaciais; Salvador.

\begin{abstract}
This article aims to clarify the relationships between urban spatial processes and migrations in an area of the city of Salvador that we call Pelourinho-Santo Antônio Axis (PSA). Our purpose was to show that the different urban spatial processes that are usually portrayed in closed schemes in the city itself can be observed in a worldwide scale. To achieve this, studies about migrations in Salvador (State of Bahia) were carried out and related to the city's urban sociospatial processes from its foundation to the current times. We found that the PSA is a center that has been receiving immigrants since the origin of the city. As time went by, new flows were gradually configured between Salvador and the world, generating a complex population mosaic in the studied area, with ethnic contributions from all the continents.
\end{abstract}

Keywords: migrations; sociospatial processes; Salvador. 


\section{Introdução}

De forma simplificada, é possível definir migrações como os movimentos populacionais que ocorrem entre dois territórios. A título de exemplificação, é possível mencionar as de âmbito permanente, as que ocorrem sazonalmente e as que se processam em movimentos pendulares (diariamente). Outra forma de classificação é estabelecida de acordo com a origem, assim o uso do termo emigrante/imigrante se refere aos indivíduos que saem de seu país (emigrante) e entram em outro (imigrante). No entanto, o conceito de migração abrange os movimentos tanto internos (que ocorrem dentro de um país) como os que se processam em países diferentes.

Esta pesquisa estuda diferentes grupos, oriundos de outras cidades brasileiras e também estrangeiras, e, por isso, o termo migração é usado para se referir ao processo de forma geral, utilizando migrações internas, para os movimentos que se processaram dentro do Brasil, e imigrações para os movimentos de origem internacional que chegaram ao País.

Já os processos socioespaciais urbanos podem ser entendidos como as mudanças que ocorrem no âmbito da cidade, impactando em suas estruturas, formas e funções. Neste trabalho, são abordados os processos de formação da cidade, de centralização, de dispersão, de invasão/sucessão e de gentrification, com o objetivo de demonstrar as relações entre eles e as migrações em uma área da cidade de Salvador, que denominamos Eixo Pelourinho-Santo Antônio (EPS). Aqui é exposta parte dos resultados de uma pesquisa que foi desenvolvida em 10 anos.

Quatro métodos de procedimento predominaram: o histórico, o comparativo, o funcionalista e o estruturalista. Tendo como procedimentos metodológicos: o levantamento bibliográfico; a pesquisa documental e em livros; a definição de periodizações, considerando as relações entre migrações, os processos socioespaciais e as transformações técnicas; análise interescalar, comparativa e relacional dos processos socioespaciais; análise das transformações das formas, funções e estruturas, tomando por referência os agentes sociais, em especial os migrantes; pesquisa quantitativa para geração de dados e espacialização das informações obtidas neles; entrevista de aprofundamento para geração de entendimentos particulares, com recortes sociais selecionados a partir do levantamento de dados quantitativos.

A seguir, será contextualizada a área de estudo, em conúbio com a exposição de alguns dos dados iniciais da pesquisa. Após isso, serão abordados os conceitos-chave nos quais se baseiam este artigo a exemplo de migrações e dos processos socioespaciais urbanos. Depois, será apresentada a primeira periodização relativa às migrações no contexto do Brasil colonial, seguida pelo contexto das mudanças estruturais no País e na cidade de Salvador, combinados com as imigrações internacionais que ocorreram no final do século XIX e início do século XX e que se processarão em conjunto com movimentos de dispersão e centralização na cidade. Após isso, é apontado o impacto dos movimentos migratórios relativos ao êxodo rural e sua relação com o processo de invasão/sucessão, ocorridos no EPS principalmente no período entre 1930 e 1980. E, por fim, são descritos os diferentes fluxos migratórios que se direcionam ao EPS a partir de 1980 e sua relação com a gentrification. 


\section{Área de pesquisa e levantamentos de informações}

O Eixo Pelourinho-Santo Antônio corresponde a bairros situados no Centro Original de Salvador e parte de sua primeira periferia, transpassando principalmente os bairros da Sé, Passo e Santo Antônio Além do Carmo e mantendo forte relação com os bairros do entorno, a exemplo do Comércio, Conceição da Praia, Santana, São Pedro, Saúde e Barbalho ${ }^{1}$ (Ribeiro, 2011, 2018a, 2018b).

É possível afirmar que a área estudada se refere à própria Salvador até início do século $X X$, que, após seu crescimento, engloba esse centro e parte da primeira periferia que passa a ser considerada como área central. Ao se observar o que ocorre no EPS, pode-se compreender os processos espaciais no restante da cidade, contudo entende-se ser mais adequado afirmar que este estudo é sobre o EPS, principalmente por conta das atuais proporções da capital baiana.

Ainda que utilizando uma análise interescalar e apesar do termo Eixo não estabelecer um limite espacial específico, adotou-se, neste trabalho, como referência para levantamentos dos dados (e posteriores comparações), a poligonal do decreto estadual de 1987 que estabeleceu e delimitou o Parque Histórico do Pelourinho (Bahia, 1987), reconhecido como Patrimônio Histórico da Humanidade pela Unesco.

\section{Levantamento de informações da população do EPS em 2011}

Com o objetivo de compreender o perfil da população do EPS, aplicaram-se formulários, em 2011, para coletar dados que foram combinados com entrevistas de aprofundamento feitas com os residentes e comerciantes da mesma área entre 2011 e 2018. Nesta pesquisa, foram levantadas informações de todas as edificações (Figura 1), dos principais logradouros dos bairros contidos na poligonal, o que não significa que foram entrevistados todos os comerciantes e moradores deles.

Com um levantamento cartográfico de 2.481 unidades imobiliárias na poligonal pesquisada, conseguiu-se algum tipo de informação sobre elas em 1.175 unidades $\cong 47 \%$; e, do total de 2.481 unidades, foram realizadas entrevistas diretas com $\cong 14 \%$, o equivalente a 344 unidades. Ressalta-se que $\cong 21 \%$ de 2.481 das edificações observadas eram institucionais ou estavam em ruína, e $\cong 13 \%$, correspondiam a casas que estavam à venda ou que os proprietários se encontravam viajando. Cada unidade, por sua vez, conta com um número específico de moradores.

Assim, se nas 344 unidades em que foram realizadas entrevistas, foram encontradas 272 unidades que estavam habitadas ou pertenciam a migrantes $\cong 80 \%$ (do total de entrevistados). Esse número multiplicado pelo número de residentes torna-se maior. Contudo, ressalta-se que, dentre os outros $20 \%$, também é possível considerar que uma 
Figura 1 - Função das edificações no Parque Histórico do Pelourinho

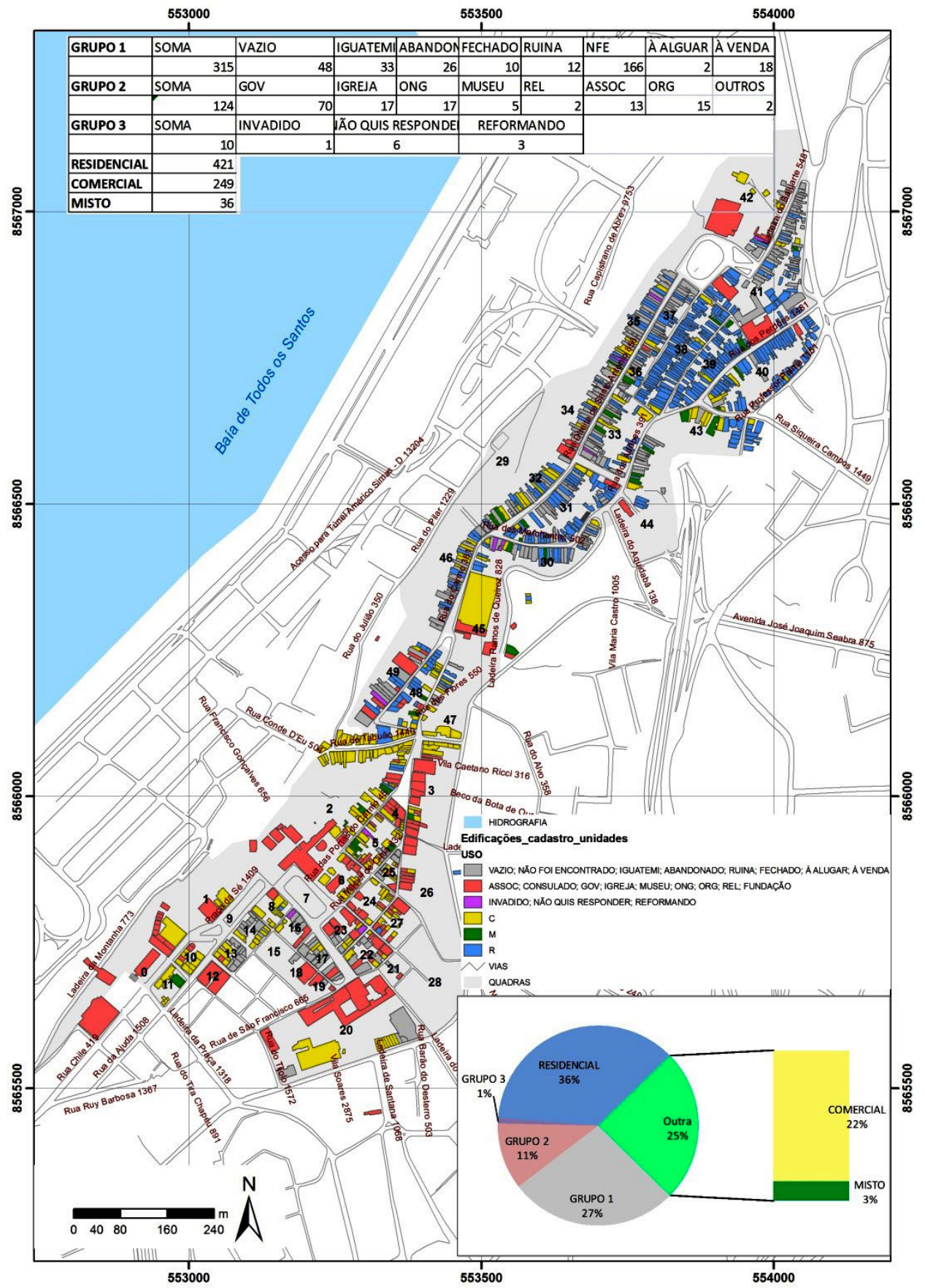

Fonte: Ribeiro (2011).

Base cartográfica: Sicar RMS 92, Sistema de Coord. SAD 1969 Projeção UTM, 24S. 
parcela é composta por pessoas que nasceram em Salvador, mas são filhos e netos de migrantes e pessoas que nasceram em Salvador, residiram em outra cidade por alguns anos e voltaram para o EPS, configurando migração de retorno. Acrescenta-se que os moradores entrevistados que chegaram após 1985 contabilizavam $\cong 60 \%$, 202 das 344 unidades pesquisadas e, nestas, contavam-se 687 pessoas (Figura 2).

Figura 2 - Mapa de tempo no lugar (em anos)

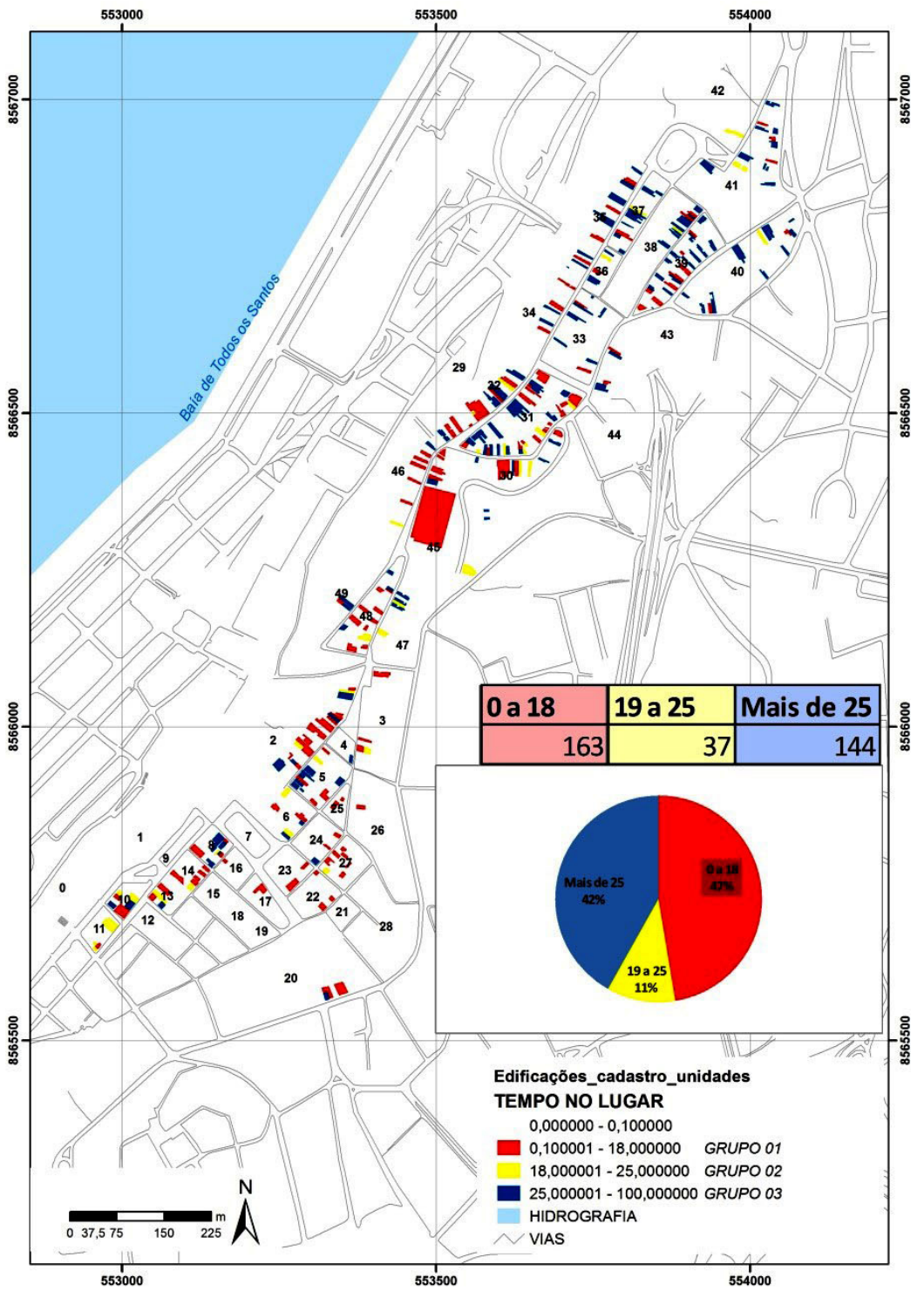

Fonte: Ribeiro (2011).

Base cartográfica: Sicar RMS 92, Sistema de Coord. SAD 1969 Projeção UTM, 24S 
O mapa de tempo no lugar aponta um percentual de $47 \%$ dos pesquisados como um possível "público gentrificador", contudo é preciso combinar essa informação com outras, a exemplo do mapa que demonstra as funções das edificações catalogadas (Figura 1), nas quais é possível identificar um número considerável de unidades vazias, algumas adquiridas por grandes instituições ${ }^{2}$ e outras cujos proprietários não se encontravam na cidade, mas que os vizinhos informaram se tratar de algum estrangeiro. ${ }^{3}$
Para contribuir com a análise, é possível demonstrar os vetores da especulação imobiliária, a partir dos levantamentos de tempo de residência no lugar e o cruzamento do valor dos imóveis que estavam à venda ou sendo alugados (Figura 3). A combinação dessas informações com a de outros dados pesquisados, a exemplo de profissão do chefe da unidade familiar, estado de conservação da residência e renda familiar, permitiu identificar o perfil socioeconômico dos grupos e, a partir disso, uma série de constatações foram alcançadas.

Figura 3 - Mapas dos vetores da gentrification e especulação imobiliária no EPS
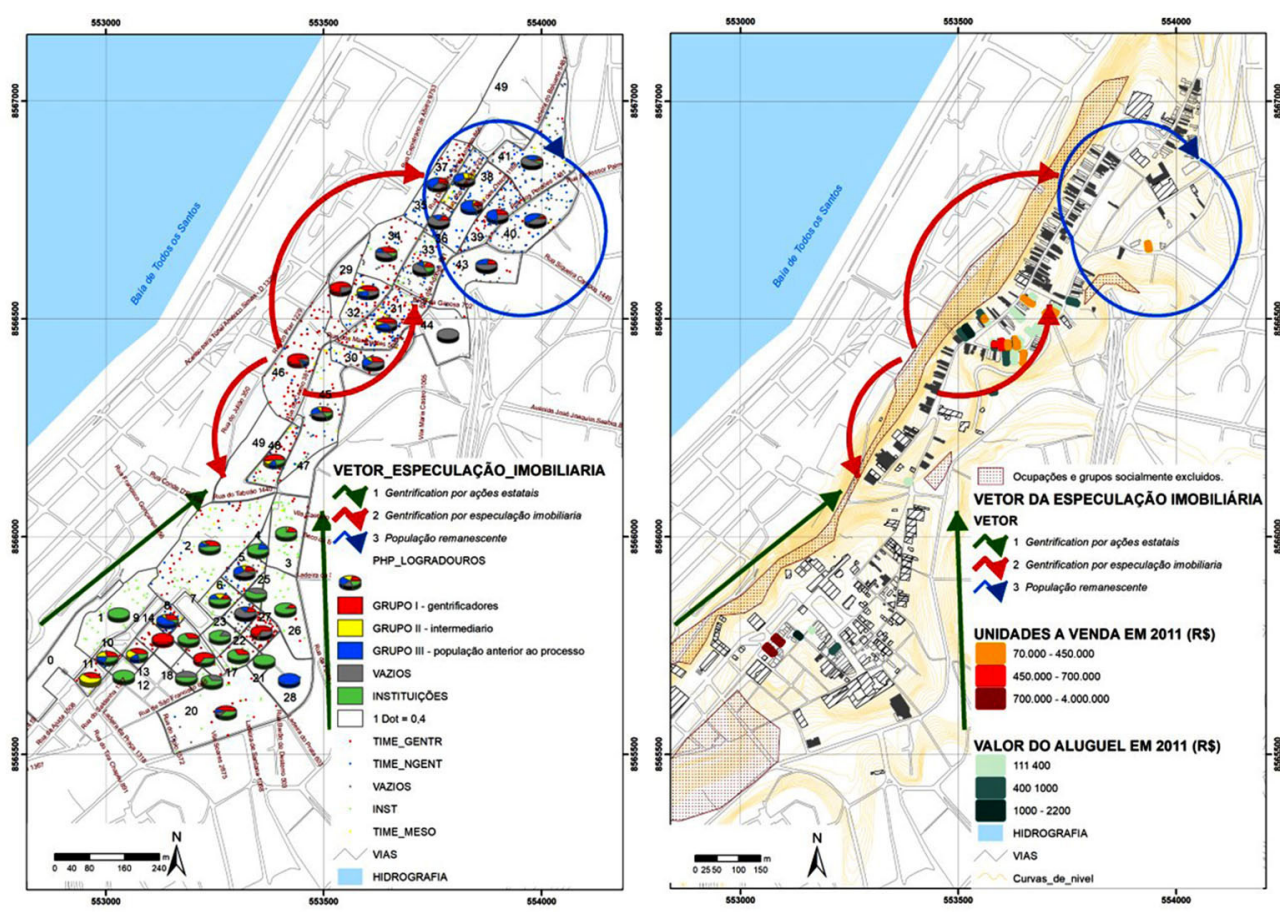

Fonte: Ribeiro (2011).

Base cartográfica: Sicar RMS 92, Sistema de Coord. SAD 1969 Projeção UTM, 24S. 
Assim, ficou evidenciado que a população que chegou posteriormente a 1985 possuía, em sua maioria, um poder aquisitivo superior ao dos moradores mais antigos. Contudo, mesmo dentre os que residiam há mais tempo, era possível identificar diferenças socioeconômicas de acordo com a origem. Só a título de exemplo, os entrevistados que se identificaram como espanhóis possuíam um padrão financeiro maior em relação à maioria dos que eram oriundos de algumas cidades da Bahia e do Nordeste, ${ }^{4}$ o que também não se constitui uma regra.

É importante salientar que estas informações são o ponto de partida desta pesquisa e não o de chegada. A partir delas, foi possível identificar que mais de $90 \%$ dos moradores e empresários na poligonal pesquisada se enquadram em algum caso relativo à migração. E os caminhos para compreender os fluxos migratórios mais antigos exigiram uma série de entrevistas de aprofundamento, nas quais novas informações foram sendo levantadas, e, com elas, complementos através das leituras de outros pesquisadores que se debruçaram sobre as temáticas de um grupo de imigrantes ou de um processo específico em Salvador.

Os estudos sobre um grupo específico consideram as gerações pós-migrações, e isso pode passar despercebido em um questionário ou formulário que não inquira a origem dos pais/avós, principalmente porque esses descendentes, corretamente, não se consideram filhos ou netos de estrangeiros e sim de brasileiros. No EPS também há uma parcela grande de migrantes de outras cidades da Bahia e muitos migrantes de diversas partes do Brasil, havendo um predomínio maior de nordestinos, com relação aos que chegaram antes de 1990 e de sudestinos e sulistas após a década de 1990.
É preciso ampliar a atenção, no caso das migrações internas, em estudos que tomem por foco o espaço e não um grupo migratório, pois o migrante (de fluxos nacionais), assim como os descendentes de imigrantes, pode não ser identificado em sua condição, diante do fato de não chamar a atenção como no caso de um estrangeiro.

Uma vez que, mesmo dentre os moradores mais antigos, as origens denunciavam diferentes padrões socioeconômicos, novas indagações surgiram. A partir disso, foram selecionados representantes dos diferentes grupos relativos ao tempo no lugar ${ }^{5}$ e origem, ${ }^{6}$ para a realização de entrevistas de aprofundamento. Com isso, identificou-se a existência de padrões migratórios na área, que antecediam ao processo de gentrification. Isso proporcionou a busca por compreender a relação entre os movimentos migratórios do passado com outros possíveis processos socioespaciais anteriores.

Se, inicialmente, no caso da gentrification, em Salvador, os resultados desta pesquisa apontaram que a população proveniente desse processo é, em sua maioria, alóctone à cidade, posteriormente se constatou que a população substituída não era, em sua maioria, nativa dos bairros, mas como será relatado a seguir, constituía migrantes e imigrantes que substituíram uma população anterior (também de imigrantes).

\section{Processos socioespaciais urbanos e migrações}

Em 1989, Corrêa (2005) escreveu sobre os processos espaciais, relacionando-os com os agentes sociais. ${ }^{7}$ Segundo o autor, esses processos são os responsáveis diretamente pela 
organização desigual e mutável nas cidades capitalistas e acrescenta que "os processos espaciais são as forças através das quais o movimento de transformação da estrutura social, o processo, efetiva-se espacialmente, refazendo a espacialidade da sociedade" (ibid., p. 36). Ainda afirma que se trata "de uma expressão empregada por geógrafos para tentar dar conta do que ocorre no espaço ao longo do tempo" (ibid., p. 37), concluindo que os processos espaciais são forjados na sociedade e, logo, de natureza social.

Em um esforço conceitual, Vasconcelos (2013) enfatiza a respeito da sobreposição dos processos no espaço, alertando para o fato de que muitas vezes formas similares terão origem em processos distintos. Sendo assim, através da geografia histórica, ele define processos e formas socioespaciais.

Os processos e formas socioespaciais são originários das mudanças atuais sobrepostas às inércias do passado. Processos mais amplos como a globalização, mudanças na economia ("pós-fordismo"), redução do papel do Estado, migrações nacionais e internacionais, sem esquecer o papel dos movimentos sociais, são fatores que modificaram as formas das cidades, criando frequentemente novas desigualdades, sem eliminar os conflitos raciais, religiosos e políticos existentes. (Ibid., p. 18)

Esse autor traz 22 exemplos de processos que classifica em três tipologias: aqueles cuja noção está ligada aos espaços, ${ }^{8}$ os que as noções estão ligadas principalmente aos indivíduos $^{9}$ e os que as noções estão ligadas aos indivíduos e aos espaços. ${ }^{10}$ Neste artigo, cinco processos socioespaciais são relacionados com os fluxos migratórios do EPS em Salvador:
Formação, Centralização, Dispersão, Invasão/ Sucessão e Gentrification. Ainda que tenha se utilizado, na pesquisa, uma base teórica mais ampla, aqui serão citados três autores como principal referência conceitual nos estudos desses processos: Corrêa (2005), Vasconcelos (2013) e Smith (1996; 2006).

Assim, partindo da explicação de Corrêa (2005), o processo de centralização tem como resultado a área central. Seu surgimento nas cidades capitalistas está relacionado com um conjunto de fatores que vão do esquema centralizador dos meios de transporte de meados do século XIX aos do século XX, sendo um produto da ação dos proprietários dos meios de produção e do Estado. A área central terá por consequência uma área periférica e como principais características: uso intensivo do solo, ampla escala vertical e limitada escala horizontal, bem como expansão horizontal limitada, concentração diurna (durante o turno de trabalho), além de ser um ponto de convergência de transportes intraurbanos e de concentração das áreas de decisões. 0 autor enfatiza que esse modelo não pode ser aplicado de forma engessada na análise das cidades brasileiras que, a exemplo do Rio de Janeiro, São Paulo e Salvador, apresentam variações de situações. Nos estudos de Santos (2008a e 2008b), Vasconcelos (2002 e 2016) e Ribeiro (2018) é possível observar essas particularidades que distinguem o modelo de centralização ocorrido em Salvador. Neste artigo, o aspecto da forma área central vem associado com os fluxos migratórios.

Para Vasconcelos (2013), a dispersão resulta na formação de "novas fronteiras" além dos subúrbios, com o surgimento de novos núcleos urbanos articulados às redes de transporte. Para o autor, ela "corresponde também 
a uma fuga dos centros muito valorizados, nos quais o valor do terreno é muito elevado e que concentram problemas de estacionamento, que levam ao seu declínio e decadência" (ibid., p. 20).

Corrêa (2005) denomina Dinâmica Espacial da Segregação, o que teria como correlato, na Escola de Chicago, o processo de invasão/ sucessão. Tomando por base os relatos de Engels, em 1844, sobre as cidades inglesas, o autor descreve o processo em que os bairros ricos do centro tradicional são abandonados pela elite e ocupados por imigrantes pobres "[...] recém-chegados, que vão trabalhar nas novas atividades centralmente localizadas. Verifica-se uma progressiva deterioração dessas mansões que se transformam em cortiços densamente ocupados" (ibid., p. 70).

No caso de Salvador, retomamos os estudos de Santos (2008b), Vasconcelos (2016) e Ribeiro (2018) como exemplos. Ainda Vasconcelos (2013) opina que, mesmo com essas áreas sendo consideradas, na literatura, como segregadas, o que ocorre de fato é o contrário, uma vez que "são o resultado da ação da população desfavorecida, que ocupa os espaços menos valorizados da cidade e que não interessa ao mercado imobiliário" (ibid., p. 30). A importância dessa visão está no fato de colocar a população menos favorecida em uma posição ativa e, assim, "não tendo condições de participar do mercado imobiliário mesmo irregular [...] ou do mercado de casas de aluguel, toma a iniciativa de invadir [...] e tentam resistir às tentativas de expulsão" (ibid.).

Por fim, o processo de gentrification que implica a substituição de uma população de menor poder aquisitivo por outra mais abastada. No entanto, para sua maior precisão, é importante considerar que esse processo conta com três recortes: o primeiro é o social, cuja raiz do nome denuncia o tipo de população que se dirige para a área. ${ }^{11} \mathrm{O}$ segundo é de caráter temporal e está situado no momento posterior ao fordismo. Em outras palavras, assim como os processos anteriores, centralização, dispersão e invasão/sucessão, são produtos da dinâmica capitalista de produção espacial, a gentrification é um novo estágio em que a lógica da mundialização e especulação se apropria de uma parcela da cidade, o que leva para o terceiro elemento. 0 recorte espacial vai delimitar a área em que o processo ocorre, sendo objetivamente em lugares centrais e/ou com forte apelo histórico, de modo a os diferenciar espaço/temporalmente do restante do espaço urbano. Nas palavras de Smith (2006, p. 63), "Seja qual for a sua forma, a gentrification implica o deslocamento dos moradores das classes populares dos centros".

\section{O impacto das migrações nos processos socioespaciais urbanos}

Na sociedade contemporânea, na medida em que o processo de mundialização é intensificado, torna-se mais difícil considerar a existência de processos socioespaciais que não tenham fortes relações interescalares. Ainda que se desdobrem em uma cidade, esses processos muitas vezes terão forças externas contribuindo para seu desenvolvimento. Considerando isso, foi proposto um esquema que relaciona os processos socioespaciais no EPS com as migrações (Figura 4).

Muitos dos autores que escreveram sobre migrações produziram conhecimentos e constatações complementares para o entendimento dos processos espaciais urbanos, 
Figura 4 - Processos socioespaciais Urbanos no EPS, considerando as migrações
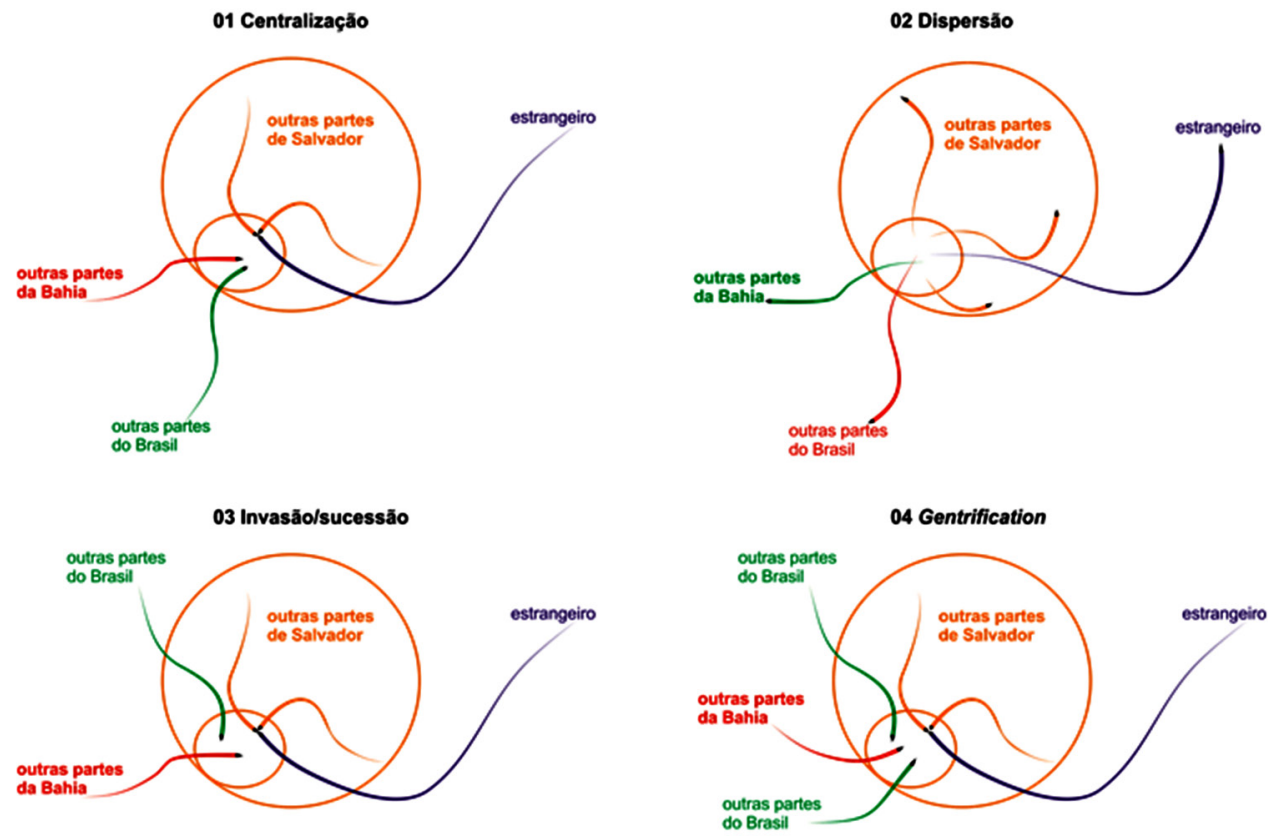

Fonte: Elaborado pelo autor.

mas, pelo fato de focarem em uma temática específica, podem ocasionar, em um leitor desavisado, a sensação de que esses processos não estão relacionados. A seguir, serão feitas conexões entre os dois temas, partindo da perspectiva dos estudos sobre migrações, mencionando desde alguns estudos clássicos até os mais recentes.

Em The Laws of migration, Ravenstein (1885) escreveu sobre a Inglaterra, Irlanda e Escócia, mas suas observações ocorreram nas paróquias rurais. 0 autor constatou que as migrações saíam de distritos rurais para manufatureiros, inclusive sendo a migração feminina maior que a masculina nas escalas municipais; mas que, em longas distâncias, o deslocamento majoritário era dos homens. Em seus dois textos (Ravenstein, 1885 e 1889), ele destacou a ideia dos fluxos e contrafluxos e que as migrações de longa distância são facilitadas pelo progresso técnico, tendendo a seguir para grandes centros industriais.

Singer (1976), analisando o Brasil, refuta que as migrações ocorridas, entre 1890 e 1930, foram internas do campo para cidade, para ele, na verdade, foram, em grande parte, transferência do campesinato europeu para as terras do País. Em seus estudos, Ribeiro (2018) constatou que, no caso de Salvador, muitos grupos de imigrantes trazidos no século XIX para colonizar o interior preferiram se estabelecer nas cidades. 
No artigo de Massey et al. (1993), sobre as teorias da migração, observou-se, pela primeira vez de forma explicita, ${ }^{12}$ a importância de tratar o tema a partir de múltiplas escalas, considerando que as diferentes correntes não se anulam, mas se complementam e, também por isso, essa teoria foi adotada como base para esta pesquisa.

Em seu livro sobre as migrações contemporâneas, Portes (2006) explica que, apesar dos migrantes representarem uma parcela pequena da população mundial, o fato de esse processo ser cumulativo e possuir fluxos bem-definidos tende a gerar impactos nas áreas receptoras. Ele menciona que as migrações e as cidades "podem ser vistas como dois lados da mesma moeda" (ibid., p. 20). Também constata que muitas vezes aquela população que hostiliza os imigrantes esquece que, em sua maioria, é descendente de filhos ou netos de imigrantes. $\mathrm{O}$ autor afirma que os laços dos imigrantes com seus locais de origem são mais um dos fatores que tornam as cidades cosmopolitas, globais.

O impacto das migrações nos processos espaciais urbanos pode ser traçado em paralelo com a análise do crescimento da intensidade dos movimentos migratórios no mundo do século passado para o atual. Quando Castles e Miller (2009) escreveram, em 1993, a Era das migrações, sinalizaram que o período entre 1850 e 1914 foi de migração transatlântica, mas que o período posterior à primeira guerra mundial será considerado, por alguns autores, como sendo o da migração em massa, principalmente devido às migrações da Europa para a América do Norte. ${ }^{13}$

Um comentário de Nuscheler (1996) que pode contribuir para a relação da migração com o processo de gentrification no EPS se refere ao perfil dos migrantes, segundo o qual os deslocamentos de grande distância e os internacionais são realizados por pessoas com melhores condições financeiras - classe média -, o que termina implicando, também, a evasão de cérebros.

Sarmento (1996) menciona que as migrações causam impactos nos processos de urbanização dos países em desenvolvimento, incluindo a favelização, que, como demonstra Santos (2008a), no livro Economia espacial, escrito em 1979, termina por acarretar o que ele conceitua como macrocefalia urbana.

Ainda que não tenha feito algum tipo de relação com os processos urbanos, consideramos válido mencionar Martins (1998) por afirmar que, em nossa sociedade, o normal é migrar; assim o problema não estaria nos deslocamentos em si, mas na reinclusão dos migrantes. É possível acrescentar que não somente a migração, mas como todo tipo de movimento é o normal para a vida, e a vida em si desconhece as lógicas dos territórios humanos. Assim, se culturalmente os territórios, e suas limitações no deslocamento, podem parecer normais, biologicamente e psicologicamente o natural para o ser humano é se deslocar em busca de melhores condições de vida. Nesse sentido, no tocante aos movimentos populacionais, os processos socioespaciais urbanos não se distinguem da lógica migratória e são uma combinação de movimentos internos e externos à cidade.

Muitos autores delineiam a relação da migração com a globalização, a exemplo de Castells (1999), ao afirmar que, na sociedade em redes, a mão de obra é global, e, nesse caso, as empresas também assumem um papel para a promoção desse deslocamento de trabalhadores, existindo, também, dois circuitos 
de migração global, o dos capacitados e o dos oprimidos. Cohen (2005) cita seis aspectos da globalização a se relacionarem com as migrações, dos quais interessa, para este artigo, o crescimento contínuo das interligações e interdependências e a sincronização de todas as dimensões envolvidas na globalização. Sassen (2007) considera que, com a globalização e mais especificamente na cidade global, as análises não podem mais ser dimensionadas somente pelos fatores de atração e repulsão, mas ganham importância as microestruturas do global. Trabalhando com modelos teóricos das redes sociais, Fazito (2010) chama a atenção para as migrações de retorno que comporiam o fechamento de um ciclo, alinhando-se com outros autores, ao considerar que a conexão entre as cidades no momento da globalização torna as análises muito mais complexas.

Vale ressaltar a premissa básica de Sayad (1998), quando afirma que todo imigrante é também um emigrante, e, se seguirmos essa lógica em paralelo aos processos socioespaciais, todo imigrante, em uma determinada cidade que contribui para composição de um determinado processo urbano, é também o emigrante de outro lugar (inclusive cidades), no qual pode ter contribuído para outro processo urbano. Assim, a migração (cidade-cidade) e os processos espaciais, urbanos e mundiais, compõem, no atual momento histórico, elementos de um mesmo movimento.

\section{Migrações - globalização primitiva e formação do centro original de Salvador - de 1545 a 1850}

0 conceito de arché geográfica trabalhado por Ribeiro (2014 e 2018b) trata sobre o primeiro processo espacial de um lugar e seus desdobramentos no tempo. Sendo assim, a arché geográfica revela, em sua tônica, elementos de permanência no decorrer do tempo. No caso de Salvador, a formação de seu centro original e primeira periferia está associada com as migrações transoceânicas no contexto da expansão colonialista portuguesa, que, no avançar do tempo, trouxeram para Salvador muito além de uma composição populacional mestiça, uma característica cosmopolita, uma vez que essa cidade em seus primeiros séculos de existência foi a mais importante da América e a segunda maior do Império Português.

A respeito da composição populacional, vemos que os portugueses, contando em seu histórico territorial com uma série de invasões, já tinham população mestiça. Carvalho (1935) menciona a mescla de diversos povos: celtas, iberos, fenícios. carthaginezes, romanos, visigodos. Darci Ribeiro (1995) detalha a respeito da contribuição dos árabes, para formação dessa população portuguesa que, ao chegar no Brasil, continuou se fundindo 
culturalmente e geneticamente com outros povos, como as populações indígenas e as distintas etnias de africanos escravizados.

Rodrigues (2010) explicou em estudo, publicado postumamente em 1932, que foram cometidos erros sobre a origem dos africanos trazidos para o Brasil, seja pela ignorância a respeito das regiões geográficas de onde procediam, seja por suas características particulares. Reclus (apud Viana Filho, 1946) comentou a respeito do desconhecimento do território africano da parte dos portugueses, que, com o avançar do processo de colonização, passaram a entendê-lo melhor. Rodrigues (2010) mencionou que os registros de Portugal dos escravizados aprisionados em guerras de tribos rivais no interior se davam nos portos de saída, o que contribuía para generalizações equivocadas. Em suas observações, ele classifica esses africanos trazidos em diversos povos, em três subclassificações dentre os Camitas africanos: 21 dentre os negros Sudaneses, 8 dentre os negros Bantos e 3 dentre os Insulani.

Considerando que, na escala mundial, o processo de formação do Centro Original de Salvador e sua primeira periferia se dão mutuamente ao processo de expansão da globalização primitiva e observando a importância dela nas relações marítimas mundiais, é possível correlacionar essas informações com a de muitos estudos isolados sobre as migrações de determinados grupos europeus para Salvador, Bahia, e/ou Nordeste.

Azevedo e Andrade apontam que muitos italianos participaram do processo de colonização na Bahia, "Durante o período colonial não devem ter faltado italianos à Capitania. Nas atas da Câmara e nas Cartas do Senado da cidade, multiplicam-se apelidos supostamente peninsulares, de sujeitos do comércio, da indústria do açúcar, da vereança" (Azevedo, 1989, p. 13). Afirmação similar foi informada por Andrade (1992), ao mencionar que houve grande participação de italianos no processo de ocupação e exploração do Brasil pelos portugueses.

Sobre a presença dos espanhóis, em especial dos galegos, na Salvador colonial, muitas menções são feitas por autores que trabalharam com o tema, a exemplo de Braga (1995), citando a presença galega na tripulação das caravelas que vieram na expedição para o Brasil o caso da Nau Santa Maria, também conhecida como a Galega -, e de Brandão (2005), que comenta a respeito da possível origem galega de Diogo Alvares Correia. Ribeiro (2018) demonstra, através de um mapa, que a proximidade espacial entre o Norte de Portugal e a Galícia é um dos elementos que explica as relações imigratórias tanto dos que vieram de Portugal, como da parte galega.

Em seus livros sobre os teutos no Brasil, Oberacker (1985) explica que havia, no período do império colonial português, dificuldades em entender quem seriam os teutos, podendo o termo se referir tanto aos alemães como aos holandeses e flamengos. 0 autor menciona que seu estudo foca nos flamengos de origem alemã e cita passagens, desde as expedições de Pedro Alvares Cabral até os empreendimentos dos engenhos de açúcar, situações que contaram também com a participação desses estrangeiros, muitas vezes imigrantes já no Brasil.

Em outros livros, que não tratam especificamente a respeito de um grupo de imigrantes, é possível encontrar as menções sobre a presença de estrangeiros vivendo em Salvador no Brasil colonial e imperial, a exemplo dos estudos de Vasconcelos (2002 e 2016) que 
trazem informações detalhadas desde a formação da cidade até o século atual, e de Nascimento (1985) cuja abordagem é feita sobre os censos de 1840 e 1860.

É possível afirmar que, na arché geográfica soteropolitana, as relações da cidade com o mundo coincidem com o início da globalização primitiva e, consequentemente, com migrações de distintos grupos europeus no contexto da expansão portuguesa colonialista, que se mesclaram com os povos nativos da América e africanos dentro desse processo, na condição (com poucas exceções) de escravizados. Esses movimentos no processo de formação do Centro original de Salvador incidiriam em um momento posterior com a expansão da cidade para os eixos norte e sul de sua primeira periferia, com os vetores de movimentos simultâneos, de centralização e dispersão, que se comunicavam com o interior dos territórios brasileiros a partir do Recôncavo baiano.

\section{Migrações e os processos de dispersão/centralização em Salvador de 1850 a 1930}

Desde a transferência da capital do Brasil para o Rio de Janeiro em 1763, Salvador foi paulatinamente perdendo sua importância política e econômica, passando do posto de principal cidade das Américas para o de capital regional brasileira. Vasconcelos (2002) informa que, em 1978, a ex-capital do Brasil transfere para o Rio de Janeiro o posto de maior porto exportador do País.

Ainda Vasconcelos (2016) afirma que, no século XIX, com a produção do café de 1820 e
1830, aumenta a importância econômica do Sudeste. Em Salvador, a guerra da independência findada em 2 de julho de 1823, com vitória das tropas baianas, gerou uma crise econômica para a cidade após a emigração da comunidade portuguesa, que acarretou a saída de importantes comerciantes e seus capitais. As revoltas ocorridas na Bahia, na primeira metade do século XIX, colocaram a província em situação antagônica ao Império. Contudo, a descoberta de diamante na Chapada Diamantina e o aumento no preço do açúcar entre 1845 e 1860 contribuíram para uma recuperação da economia baiana.

Em 1850, a Lei Eusébio de Queirós proíbe o tráfico de escravos, mas a pressão inglesa contra essa atividade antecedia a lei em três décadas, o que incentivou a elite baiana a buscar mão de obra em outros países, visando a substituir o trabalho escravo e "civilizar" o interior da província. Algumas colônias de imigrantes italianos, trazidos com essa finalidade, datam dos anos 1840, como informa Azevedo (1989).

Na segunda metade do século XIX, eventos internacionais trazem impactos à Bahia. Vasconcelos (2002) comenta que, em 1858, a linha de navegação a vapor entre Inglaterra e Brasil reduz a importância do porto de Salvador, melhor para as embarcações que utilizavam correntes marítimas, valorizando portos mais próximos da Europa, como o de Recife. Segundo o autor, a Guerra de Secessão (EUA) contribuiu para a expansão da cultura do fumo no Recôncavo baiano; além disso, ocorreram a Guerra do Paraguai, que levou 18.725 homens da Província, e a crise financeira internacional de 1873/1890, que reduziu as exportações dos produtos baianos. 


\section{Dispersão da elite soteropolitana, portugueses e ingleses}

Dois foram os principais movimentos de dispersão que ocorreram em Salvador na segunda metade do século XIX. Gradualmente, com a perda de poder econômico e prestígio social e político, há a mudança dos que na cidade residiam para os novos vetores econômicos do Império, posteriormente país. Ao mesmo tempo, há a saída dos grandes comerciantes portugueses após a guerra da independência. Com esses dois processos, inicia-se um movimento em direção ao Sul da capital baiana, encabeçado pelos comerciantes ingleses "cuja importância na cidade crescera a partir de 1808, com a abertura dos portos" (Palácios, 2009 , p. 39), que, valorizando "jardins, pomares, ar limpo e espaços amplos e ventilados, ausentes nas construções coloniais do centro, coladas umas às outras" (ibid.), deslocaram-se para áreas mais afastadas e atraíram a população soteropolitana mais abastada, que passou a se estabelecer no Campo Grande e Vitória. Esses movimentos de dispersão ocorriam para o Sul da cidade, mas também para fora dela e, combinados, geraram gradativamente unidades imobiliárias vazias no centro que, ao mesmo tempo, passaram a ser ocupadas pelos que nele chegavam.

\section{Migrações internas e imigrações euroasiáticas no processo de centralização}

É interessante destacar que na sociedade vigente no Brasil do século XIX, em Salvador, a maioria dos pretos da cidade eram africanos ou seus descendentes diretos. Somam-se a isso, outros grupos de estrangeiros, que, em sua maioria, dominavam os estabelecimentos comerciais soteropolitanos. Assim, é possível chegar sem dificuldades a mais da metade da população da capital baiana sendo composta por estrangeiros ou descendentes - ainda que muitos no contexto escravagista.

Nos estudos de autores sobre o século XIX em Salvador, é possível perceber que tanto os movimentos de migrações quanto os de imigrações foram comuns na cidade nesse período. Nascimento (1985) traz relatos de estrangeiros habitando a cidade em meados do século XIX, dentre eles, franceses, suíços, alemães e, inclusive, africanos livres, ricos e proprietários de escravos. Vasconcelos (2016) comenta, a respeito de estrangeiros, que foram importantes agentes sociais na cidade e menciona episódios no qual fluxos populacionais de outras partes do Nordeste se dirigiam para a capital baiana, a exemplo de 1877 , quando cerca de 780 retirantes cearenses que fugiam da seca foram acolhidos nela.

Contudo, além dos ingleses, quatro grupos principais recebem destaque neste artigo. Primeiro porque foram mais expressivos em quantidade e segundo porque esses grupos constituíram colônias que atravessaram o século XX e se espalharam pelo interior da província, posteriormente estado da Bahia. São eles italianos, galegos, árabes e portugueses. ${ }^{14}$

O porto de Salvador era o principal ponto de entrada desses imigrantes que se destinavam a diferentes cidades do interior da Bahia. A região que atraiu maior contingente populacional foi a cacaueira, devido ao apogeu dessa cultura que chegou a representar 90\% do PIB da Bahia, segundo informa Tavares (2008) ou nas explicações de Santos (2008b). Assim, o impacto das migrações (brasileiros) 
e imigrações em Salvador foi amortizado até a década de 1930, quando a cultura do cacau entra em crise.

Outro aspecto a se considerar é o das migrações que os comerciantes faziam frequentemente indo da capital para diferentes áreas do interior, comprando e vendendo produtos em ambas as localizações. Os caixeiros viajantes portugueses, os mascates árabes e os carcamanos italianos estabeleciam rotas comerciais entre Salvador e as cidades do interior e, em muitos casos, suas estadias na primeira se davam em pensões localizadas no centro (Figura 5).

Figura 5 - Fluxos dos imigrantes entre Salvador e outras cidades da Bahia (séc. XIX e XX)

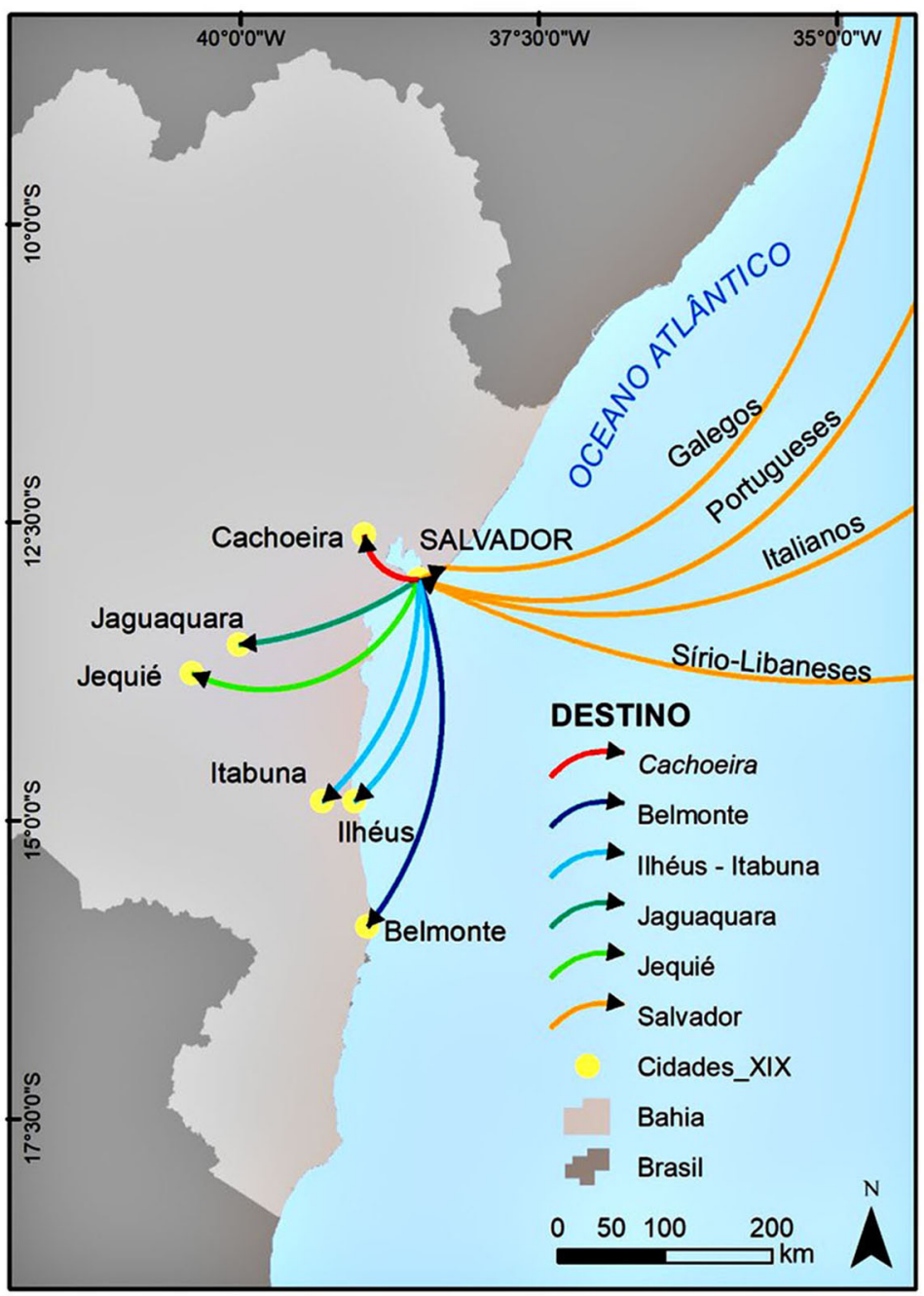

Fonte: elaboração própria. Projeção WGS84. 
O mapa que aponta alguns dos fluxos estabelecidos por esses imigrantes foi produzido com base em registros em livros, observações de campo e entrevistas. Vale ressaltar que existiram outras rotas e colônias que não puderam ser confirmadas em alguma fonte e, por isso, não foram ilustradas.

Com muitos desses migrantes e imigrantes se estabelecendo no centro e em seu entorno imediato, o processo de dispersão envolvendo a saída dos mais abastados foi acompanhado da gradativa substituição por uma população com menor poder aquisitivo, mas que, em muitos casos, conseguiu ascender na sociedade soteropolitana. Assim, esses imigrantes se organizam social e politicamente de modo a se tornarem importantes agentes na cidade. A título de elucidação, de suas sociedades surgiram hospitais e clubes, como o português e espanhol, ou casas culturais, como a casa da Itália e o Gabinete Português de Leitura.

Muitos dos italianos trazidos desde a primeira metade do século XIX e em todo o seu decorrer, para colonizar áreas interioranas da província da Bahia, estabeleceram-se em Salvador, por encontrar oportunidades de trabaIho. Dentre os ofícios, que iam do artesanato a afinadores de pianos, contribuíram culturalmente com operas, publicadas em jornais por professores de piano e canto, e, no início do século XX, com artistas italianos (alguns trazidos de São Paulo) que foram contratados para embelezar a fisionomia das edificações.

Os Chirico, os Conti, os Santoro, os Rosi, os Sorceli e tantos outros, diferentes entre si nos misteres e nos méritos, trabaIharam com afinco, brindando a cidade ora de bronzes e mármores duradouros, ora de pinturas de salão mundano em igrejas austeras e, ainda, em edifícios públicos e particulares, da glace caricatural dos estuques, as grinaldas, os festões, as águias de bico voraz e asas abertas, e, até, de mulheres aladas ou de corpo natural inteiro, todas elas de seios duros e pontudos de Dânae de Corregio, por onde se pudessem modelar, acaso, as taças cônicas das festanças inaugurais. (Azevedo, 1989, pp. 32-33)

Andrade (1992) informa que havia, na Bahia, uma dinâmica comunidade de italianos que se interiorizou, constituindo importantes colônias principalmente no sudeste da província, a exemplo de Jequié e Poções. Em Salvador, alguns desses imigrantes enriqueceram, como os Vitta, com a fábrica de bebidas: Fratelli Vita.

Os espanhóis, em sua maioria galega, constituíram, em Salvador, a maior colônia de estrangeiros na cidade. Com muitos estabelecimentos comerciais, fundaram um time de futebol, o Galícia, que ganhou títulos estaduais e regionais, hoje com outras modalidades, como rugby e futebol feminino, também com títulos. Alguns de seus descendentes enriqueceram e são proprietários de empresas baianas de porte internacional.

Os sírios e libaneses constituíram uma colônia árabe em parte do EPS, e sua comunidade, apesar de ter se adaptado bem aos ritos da Igreja Católica Apostólica Romana, contou por algum tempo com uma Igreja Católica Maronita na cidade, pois eram, em sua maioria, cristãos maronitas. Parte seus descendentes também ascendeu socialmente, como se constatou nas entrevistas realizadas.

Nos relatos de Nascimento a respeito do recenseamento de 1850 , há a menção aos portugueses como comerciantes de prestígio em muitas das freguesias soteropolitanas. Santos 
publicou dois livros (Santos, 1977 e 2009), nos quais demonstra a existência de portugueses comerciantes ricos e também de uma grande quantidade de funcionários que eram trazidos ainda crianças de Portugal e explorados por seus patrões. Gandon (2010) classifica as migrações portuguesas desse período como espontâneas e contratadas e explica que a segunda foi considerada nociva por uma comissão parlamentar portuguesa de 1873 . Os patrões e funcionários, muitas vezes, entravam em conflitos de interesses. Os funcionários fundaram cinco associações, já os grandes comerciantes participavam da Associação Comercial da Bahia, que contava com empresários ricos de diversos países, principalmente Portugal, que chegou a superar os brasileiros na quantidade de representantes da diretoria de 1900/1904. Segundo Martins (1956), os portugueses detinham o monopólio do comércio de retalhos em Salvador no século XIX.

\section{Considerações parciais}

Durante o século XIX e início do século XX, Salvador ao mesmo tempo que perdia população para outras cidades economicamente mais dinâmicas do País, recebia imigrantes de regiões que eram polos de repulsão populacional, a exemplo da Espanha, Itália, Síria, Líbano e Portugal, além de migrantes oriundos de áreas pouco dinâmicas do Nordeste brasileiro. Também despontava como um lugar oportuno para investimentos, o que atraia o capital estrangeiro e com ele alguns de seus investidores.

Ao mesmo tempo, Salvador exerce um papel de ponto intermediário entre o fluxo da Europa para o interior da Bahia e de principal destino dos que exerciam rotas comerciais entre o interior e ela. Assim, havia na cidade um movimento migratório de entrada e saída populacional, que era coincidente com os processos socioespaciais urbanos de dispersão e centralização.

\section{Dispersão populacional do EPS e relação entre o êxodo rural e a invasão/sucessão, de 1930 a 1980}

Da década de 1930 até meados de 1980, o Brasil passou por mudanças estruturais que influenciaram diretamente as migrações que se dirigiram a Salvador e consequentemente na expansão e nos processos socioespaciais ocorridos nela. No EPS, a primeira periferia do centro original foi deixando de ser periférica com a expansão da cidade e se tornando central. Sendo assim, a partir do século XX, os processos ocorridos no EPS não incluem todos os processos socioespaciais na capital baiana, mas são fundamentais para compreender aqueles ocorridos na cidade e sua relação com o espaço geográfico.

Segundo Santos (2008b), com o declínio da mineração aurífera em Minas Gerais e do diamante na Bahia, há, no final do século XIX, um movimento de volta ao litoral, de modo que, em 1872, Salvador possuía 128 mil habitantes e passa para 206 mil em 1900, número cinco vezes maior que os 40 mil do final do século XVIII.

Tavares (2008) informa que, no início do século XX, há um aumento da comunicação das redes de transporte rodoviário, ferroviário e marítimo na Bahia e, segundo Vasconcelos (2016), entre 1890 e 1920, a economia 
baiana recupera-se com a produção cacaueira. A região cacaueira amorteceu o impacto das migrações na capital baiana, mas isso se rompe, a partir da década de 1940, com a crise da Vassoura de Bruxa. Ao mesmo tempo, com a Primeira Guerra Mundial (1914-1918), inicia-se a industrialização de substituição no Brasil que tem, por consequências, a concentração de investimentos em São Paulo, que já passava a deter o poder econômico após a cultura cafeeira assumir o protagonismo nas exportações nacionais. Esses fatos coincidiram com o período republicano. Na escala local, os políticos em Salvador também buscavam a modernização da cidade, com a implantação de novos equipamentos e o seu embelezamento, a exemplo do já citado caso dos artistas italianos trazidos com essa finalidade.

No âmbito legal, a Lei de Cotas de Migração de 1934 contribuiu para a diminuição e a seleção dos imigrantes que entravam no Brasil, reduzindo o número de indivíduos para um percentual estabelecido sobre os que já residiam no País e também limitando as entradas para cinco portos, dos quais o de Salvador estava incluso. Sendo assim, apesar das cotas, a entrada de alguns grupos continuou ocorrendo, enquanto os seus países permaneciam instáveis, a exemplo de Espanha e Portugal; já outros povos foram hostilizados ${ }^{15}$ pela população soteropolitana, principalmente com a Segunda Guerra, após o episódio do torpedeamento de navios brasileiros. Nesse processo de expansão do capitalismo no mundo, detalhado por Harvey (2005), ${ }^{16}$ e seus desdobramentos no Brasil, o maior impacto foi sentido no campo, pois, como explicam Priore e Venâncio (2013), a respeito do debate sobre as alterações das estruturas agrárias brasileiras,
Em torno dele se chocam interesses econômicos e paixões políticas. Não por acaso, nem mesmo governos transformadores, como os de Getúlio Vargas e Juscelino Kubitschek, instituíram projetos dessa natureza. Na verdade, pode-se afirmar o inverso. Desde os anos 1930, a ênfase dada à industrialização leva, na maioria das vezes, a restrições ao crédito rural e a uma política cambial desfavorável aos produtores agrícolas. Assim, para a manutenção das taxas de lucro, deve-se aumentar o nível de exploração dos trabalhadores, o que estimula, por sua vez, movimentos migratórios e sentimentos de revolta. (p. 273)

Esse processo favorecido pela rede viária teve inúmeros fatores que o impulsionaram, aspectos psicológicos, econômicos, macroestruturais, dentre outros. Se, por um lado, ocorriam forças de repulsão no campo; por outro lado, a cidade aparecia como área de atração e, no caso de Salvador, um fator vai impulsionar os fluxos em sua direção.

Em 1939, a descoberta do primeiro poço de petróleo do Brasil acontece em Salvador no Lobato - e, como relata Oliveira (1987), na década de 1950 é instalada uma pequena refinaria em Mataripe. O Recôncavo baiano será o único produtor de petróleo no Brasil por três décadas, o que também contribuirá para a atração de migrantes, o que desencadeou a macrocefalia em uma Salvador que não estava preparada para receber aquele contingente populacional, ao tempo que não contou com o amortecimento do impacto das migrações por uma rede de cidades médias no seu entorno. Santos (2008b) informa que, entre 1940 e 1950, Salvador recebeu 89.671 imigrantes, ${ }^{17}$ entre os quais $70 \%$ tinham como origem o interior do estado 
da Bahia, havendo maior concentração na parte Norte da cidade, como afirma Vasconcelos (2002). Esse processo se intensificará nas décadas seguintes repercutindo também no EPS.

\section{Processos de dispersão e invasão/sucessão}

Esse novo momento do País, iniciado nos programas desenvolvimentistas de Vargas e nos governos que o sucederam, combinou o processo de dispersão com os de invasão/ sucessão. No que concerne à dispersão, uma série de medidas, tomadas no início do século $X X$, contribuiu para a desvalorização crescente do centro, principalmente na freguesia da Sé, com o episódio da concentração do meretrício da cidade no Maciel (Palácios, 2009). O Passo e o Santo Antônio Além do Carmo tornaram-se os destinos de muitas famílias de classe média ${ }^{18}$ que residiam na Sé, enquanto alguns dos antigos imigrantes que já haviam enriquecido se mudaram para outras partes da cidade, principalmente ao Sul, como a Graça, Barra e Ondina.

O esvaziamento dos grandes sobrados da Sé e a desvalorização dessa área, combinados ao êxodo rural, vão mudando gradativamente a estrutura social e também sua paisagem, o que, posteriormente, se estende para as áreas circunvizinhas, como o Passo, Saúde, São Pedro, Santana, Comércio, Santo Antônio. Assim, os processos de invasão/sucessão configuraram-se no EPS e seu entorno, por quase todo o século $X X$.

Contudo, sem aprofundar a observação localmente, é possível cometer generalizações equivocadas. É importante destacar que diversos extratos sociais compunham a área em questão, tornando-a extremamente diversificada, social e economicamente. Santos (2008b) explica que quatro tipos diferentes de rua se constituíam no Centro de Salvador, as originariamente sem população, as que tiveram a perda de habitantes entre 1940 e 1950 , as que estavam despovoando e as ruas que tinham aumento populacional. Segundo ele, havia diferentes causas para a diminuição populacional, como a crise de moradia e a especulação imobiliária, ocorrendo um aumento e redução desforme que variavam de uma rua para outra. "É assim que uma mesma paisagem, a das velhas casas do centro, pode abrigar duas tendências demográficas diferentes, até mesmo contraditórias" (ibid., p. 142).

\section{Migrações e gentrification no EPS de 1980 a 2019}

Diante da situação que se encontrava o conjunto urbanístico do EPS, principalmente no Maciel, desde a década de 1970, o Estado buscava medidas para preservar as edificações, tendo em vista a possibilidade de desenvolver um plano turístico para ele. Com algumas tentativas que não resultaram efetivamente no que se pretendia, a exemplo da primeira etapa do Plano de Recuperação do Pelourinho em 1971, sucedida de diferentes propostas e projetos, que tiveram como ponto culminante a criação do Parque Histórico do Pelourinho em 1987, seguida pelo Programa de Recuperação do Centro Histórico (1991-2006). ${ }^{19}$ Por esses e outros motivos, ${ }^{20}$ definiu-se, nesta pesquisa, que os anos 1980 foram transitórios, entre o período anterior e o novo que se iniciou na década de 1990, cuja tônica principal foi a da substituição 
da população pobre do EPS, por moradores e comerciantes com maior poder aquisitivo, caracterizando, assim, os três principais fatores (social, espacial e temporal) que enquadram esse processo como o de gentrification.

Não somente os números crus, mas as observações em campo, auxiliadas pelas entrevistas de aprofundamento, permitiram constatar que o processo de gentrification no EPS passou por quatro fases, sendo três delas coincidentes com o que Smith (1996 e 2006) chama de ondas de gentrification. Essas ondas, por sua vez, se relacionam com diferentes momentos e movimentos migratórios nacionais e internacionais.

A primeira onda - esporádica - inicia-se na década de 1980 e é caracterizada por um momento transitório entre o êxodo rural e a chegada de estrangeiros que, se encantando com a paisagem no Pelourinho e posteriormente no Santo Antônio, adquirem residências, as reformam e passam a morar nelas. Esse processo se estendeu e intensificou por toda década de 1990. Contudo esse período contou com algumas ações do Estado que contribuíram para a sua consolidação, principalmente em parte da antiga freguesia da Sé, agora conhecida como Pelourinho.

A segunda onda - consolidação - inicia-se em meados da década de 1990 e se expande por toda a década de 2000 , quando as ações governamentais, voltadas para a promoção de Salvador no circuito turístico internacional, combinadas com eventos que colocaram a cidade em maior evidência no mundo, ${ }^{21}$ contribuíram para a atração de muitos turistas, que posteriormente se tornaram imigrantes. A maioria deles oriundos da Europa, mas com representatividade em mais de um país em todos os continentes.
Com isso, a consolidação da gentrification no EPS ocorreu com a combinação de ações direcionadas pelo Estado em retirar a população pauperizada que residia em suas edificações e atrair um público turístico para ela. Uma parcela desses turistas posteriormente torna-se moradores e, dessa forma, mais uma vez, os processos socioespaciais no EPS configuram-se com uma forte contribuição dos processos relacionados às migrações.

A terceira etapa da gentrification - generalização - não consegue se configurar plenamente como um quadro estabelecido, contudo ela se dá em certo grau, ao surgirem projetos promovidos por empresas internacionais e de grande porte em áreas próximas ao EPS, 22 e no caso especificamente do Santo Antônio, com a ação do Holding LGR, empresa que adquiriu mais de 40 edificações no bairro, com o intuito de promover um grande empreendimento. A ação do Holding LGR, combinada a todos os eventos anteriores, resultou em uma alta da especulação imobiliária no bairro, elevando em alguns casos, para mais de um milhão de reais, o valor das casas que, nos anos 1990, eram vendidas por 30 a 50 mil reais.

Outras ações em escala internacional por parte do governo brasileiro facilitaram, nos anos 2000, a circulação dos imigrantes latino-americanos, o que contribuiu para um fluxo de sul-americanos para Salvador, principalmente os chilenos e argentinos. Esse grupo que veio atraído pela cultura soteropolitana, mas também pela facilitação governamental, é o que vai permanecer em maior quantidade na quarta fase identificada nesta pesquisa.

Em 2011 se inicia um processo de desaquecimento no mercado imobiliário no EPS, o que se agrava após 2014. Se, por um lado, muitos dos europeus que chegaram aos anos 
1990 viram, no final da década de 2000, a possibilidade de lucrar vendendo os seus imóveis; por outro lado, outros que permaneceram após 2011 começaram a rever se gostariam de envelhecer em Salvador ou em seus países de origem, com um sistema social mais eficiente. A saída dos europeus ocorre simultaneamente com a chegada de brasileiros de classe média oriundos de diversas partes do Brasil, principalmente Sudeste, e também de sul-americanos. Esse novo público, somado a todas as "camadas" de moradores que permaneceram, contribuiu para tornar a população do EPS ainda mais heterogênea.

\section{Considerações finais}

Ainda que não se possa generalizar a seguinte afirmação, é possível considerar, nos estudos sobre as cidades, que cada processo socioespacial não se restringe aos seus limites. Observando a realidade de uma metrópole regional como Salvador, demonstrou-se que, desde o seu primeiro processo de formação até o atual momento, em uma área que se denomina EPS, houve uma grande influência dos processos mundiais e nacionais, assim como dos fluxos migratórios nacionais e internacionais em cada etapa de seu desenvolvimento urbano.

Com isso, a formação da cidade, centralização, dispersão, invasão/sucessão e gentrification, foram combinados com movimentos populacionais de migração, emigração e imigração. Ambos, processos urbanos e migratórios, foram influenciados pelos processos de escala nacional, como as movimentações econômicas no território brasileiro e as ações políticas, além dos processos em escala mundial, como a mundialização e eventos de impacto internacional, como a Segunda Guerra Mundial.

Ao final da pesquisa, constatou-se que aproximadamente, $90 \%$ dos entrevistados não nasceram em Salvador. Para demonstrar esses dados, elaborou-se uma série de mapas-síntese que apontam as origens da população entrevistada, antes e após 1985. Com a comparação espaço temporal dos mapas, é possível uma melhor compreensão das informações levantadas (Figura 6).

Os dois primeiros mapas mostram a origem dos migrantes baianos que chegaram antes e após 1985, seguindo o mesmo critério para os dois mapas seguintes, relacionados aos migrantes brasileiros, e o último aponta a origem dos imigrantes entrevistados. Ambos possuem a quantificação por lugar, lembrando que cada entrevistado pode ter mais membros na unidade imobiliária em que reside e, assim, esse número não representa a população, mas a origem do responsável pela unidade imobiliária em que ocorreram as entrevistas.

Analisando os dados pesquisados e a sua espacialização, é possível extrair uma série de constatações. A constatação de maior interesse para o presente artigo leva à conclusão de que, ainda que qualitativamente os grupos isolados tenham oferecido importantes contribuições para a cidade; quantitativamente, não possuem maior expressividade no século XXI.

Assim, a combinação de dois caminhos permitiu caracterizar o EPS como uma área receptora de migrantes. 0 primeiro caminho implicou pesquisar a origem de todos os moradores da área e não um único grupo migratório. O segundo, iniciado com as entrevistas de aprofundamento, levou à percepção de que outros fluxos migratórios (nacionais e 
Figura 6 - Origem dos imigrantes no EPS
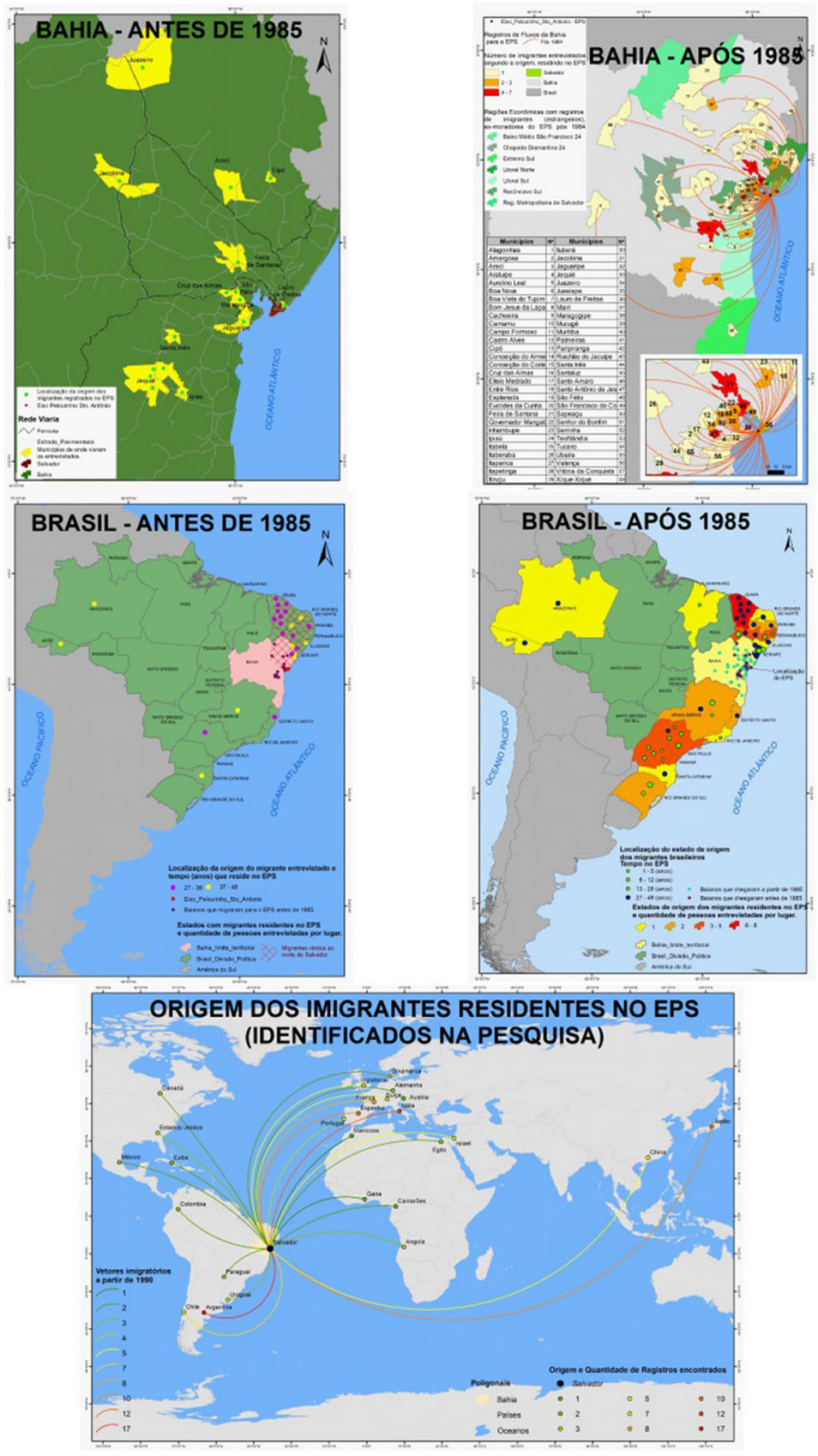

Fonte: elaboração própria. 
internacionais) ocorreram em períodos anteriores. A partir disso, compreendeu-se que uma parte dos entrevistados que nasceram em Salvador era filhos ou netos de migrantes.

Com isso, percorrendo um caminho pela Geografia Histórica, montou-se o mosaico populacional da população do EPS, chegando à constatação de que os fluxos migratórios nacionais e internacionais, que sempre ocorreram em direção a essa área, deram-se em diferentes contextos espaço temporais. Vale salientar que, por mais de um século, o EPS e seu entorno consistiam na própria cidade de Salvador.

Ainda sobre os mapas-síntese, a menor presença de baianos e brasileiros que chegaram antes de 1985 revela que parcela considerável dessa população mais antiga foi substituída pelos novos moradores. Além disso, a própria origem diversificada dos que chegaram após 1985 aponta um maior grau de articulação entre os territórios e o mundo.

Ao mesmo tempo, a maior presença de sulistas e sudestinos que chegaram após 1985 indica maior complexidade nos fluxos migratórios internos no Brasil, nos quais é latente um movimento que vai do Sul/Sudeste para o Norte do País e que não necessariamente consistem em migração de retorno.

As entrevistas de aprofundamento permitiram identificar diferentes perfis dos migrantes. No entanto, algumas características foram marcantes na maioria dos entrevistados. No caso dos europeus, em sua maior parte, eles consistiam em um público de classe média em seus países, mas o dinheiro valorizado, no Brasil, permitiu um aumento da qualidade de suas vidas. Os japoneses, dentre outros estrangeiros (incluindo europeus), consistem em um grupo que faz migrações sazonais, ficando parte do ano trabalhando em seus países e outra parte vivendo no EPS.

Os latino-americanos, em sua maioria, constituem um grupo de menor poder aquisitivo. Os motivos que os levaram a Salvador estão relacionados com a apreciação pela cultura baiana, além das facilidades que ocorreram a partir do estreitamento de relações diplomáticas entre o Brasil e os países vizinhos, principalmente no século XXI. Perfil semelhante têm os brasileiros presentes no EPS, mas que possuem maior diversificação de casos, desde empresários que adquirem edificações, até estudantes que dividem o aluguel dos sobrados (barateando os custos), prática muito comum entre os jovens de todas as origens - europeus, orientais, africanos, latinos e norte-americanos. Outro exemplo é o de casas em que os proprietários alugam quartos para estrangeiros.

O complexo mosaico populacional do EPS no presente é a combinação de diferentes fluxos migratórios que fazem parte da realidade da cidade de Salvador, desde a sua formação, e que se ampliou no avançar do tempo. Com isso, mais do que processos socioespaciais urbanos, a cosmopolita Salvador tem desdobrado, em seu território, a expressão local dos processos mundiais. Resultado de séculos de combinações populacionais, o caldeirão cultural soteropolitano evidencia-se na geografia da cidade, rica em técnicas, cores, cheiros e sabores, no qual a cultura e a história servem de atrativo para mais diversidade, que, mesclando o novo com o já existente, continua a produzir novos processos na cidade. 


\section{[I] http://orcid.org/0000-0003-3483-4794}

Universidade Federal Fluminense, Instituto de Geociências, Programa de Pós-Graduação em Geografia. Campos dos Goytacazes, RJ/Brasil.

danalbrib@gmail.com

\section{Notas}

(1) Alguns dos bairros citados correspondem a referências das antigas freguesias da cidade, trabalhados em estudos como os de Nascimento (1985) e Vasconcelos (2002; 2016). Atualmente, as divisões de bairros da cidade elaboradas pela prefeitura municipal não correspondem mais a esses limites.

(2) A exemplo do Holding LGR com mais de 40 aquisições no momento da pesquisa, além de empresas hoteleiras, como o grupo Pestana, que adquiriu o Convento do Carmo o transformando em um Hotel.

(3) Muitos europeus e japoneses fazem migrações sazonais, ficando alguns meses no EPS e trabalhando a outra parte do ano em seus países de origem. Outros são proprietários de mais de uma edificação na área (alguns chegando a ter mais de cinco).

(4) O detalhamento do questionário, dados obtidos e informações geradas a partir deles, bem como das entrevistas realizadas, podem ser encontrados em Ribeiro (2011 e 2018a).

(5) Anteriores a 1990 e os que chegaram nas décadas de 1990, 2000 e 2010.

(6) Foram considerados os que nasceram na cidade, em outros municípios baianos, outros estados brasileiros e outros países.

(7) O conceito de agentes sociais foi desenvolvido anteriormente por outros autores, a exemplo de Form (1954), Capel (1972) e no Brasil por Bahiana (1978).

(8) São eles: diferenciação socioespacial, desigualdade socioespacial, justaposição, separação, dispersão, divisão em partes e fragmentação.

(9) São eles: exclusão e Inclusão (espacial).

(10) São eles: segregação, dessegregação, apartheid, autossegregação, agrupamento, fortificação, polarização, dualização, gentrification, invasão, marginalização (espacial), periferização e abandono de áreas.

(11) Uma alusão a uma pequena nobreza rural inglesa. Em outras palavras, não são os mais ricos (nobres) da cidade.

(12) Alguns autores fizeram relações similares antes de Massey et al., a exemplo de Beaujeu-Garnier (1980) que escreve sobre as migrações e processos espaciais urbanos, ainda que não afirmando se tratar disso.

(13) Outros países do continente americano também receberam uma grande quantidade de imigrantes europeus, a exemplo do Brasil e da Argentina. 
(14) Os portugueses, em especial, seriam outro fluxo migratório que se deu posteriormente à saída dos comerciantes lusitanos após a Guerra da independência da Bahia.

(15) Italianos e alemães tiveram suas lojas depredadas, e isso contribuiu para a saída desses grupos da cidade.

(16) O autor explica o processo de investimento do excedente de capital em outros territórios, como uma forma de expansão imperialista.

(17) Não se conseguiu distinguir se o autor inclui na lista de imigrantes os estrangeiros, mas compreende-se que, conceitualmente, a maior quantidade desse número se refere aos migrantes oriundos do êxodo rural.

(18) Muitos destes, foram imigrantes que conseguiram ascender economicamente com as atividades de comércio. Em parte da rua Direita do Santo Antônio e do Passo, existiu uma colônia árabe, cujos moradores em sua maioria eram libaneses ou descendentes.

(19) Esse programa foi controverso em muitos sentidos, principalmente em suas primeiras etapas, tendo sido criticado por muitos que o acusaram de promover a limpeza social do Centro e aplaudido por outros pelas ações de restauração de muitas edificações que se encontravam em estado precário de conservação.

(20) Existem diferentes aspectos que convergem para se considerar os anos 1980 como um período transitório entre épocas. A título de exemplo, pode-se citar o cenário político brasileiro que migrava de uma ditadura para uma democracia. Em termos de mundo, vivenciaram-se os últimos anos da guerra fria, enquanto os embriões da nova ordem mundial já estavam fecundados e desenvolvidos.

(21) Há uma lista de elementos que contribuíram para uma difusão maior da cidade no mundo, dentre eles, o sucesso da banda percussiva Olodum, que gravou clipes com astros como de Paul Simon e Michael Jackson.

(22) Vale a menção da tese de Mourad (2011), que estuda o processo em outras áreas da cidade, apontando a existência de projetos de grande porte que configurariam a própria generalização do processo.

\section{Referências}

ANDRADE, M. C. (1992). A Itália no Nordeste, contribuição italiana ao Nordeste do Brasil. Recife, Massangana.

AZEVEDO, T. de (1989). Italianos na Bahia e outros temas. Salvador, EGBA.

BAHIA (1987). Decreto estadual n. 7.984 de 4 de setembro de 1987.

BAHIANA, L. C. C. (1978). Agentes modeladores e uso do solo urbano. Associação de Geógrafos brasileiros. Anais... Rio de Janeiro, n. 18, pp. 53-62.

BEAUJEU-GARNIER, J. (1980). Geografia de população. São Paulo, Nacional. 
BRAGA, C. M. L. (1995). Memórias de Imigrantes Galegos. Salvador, Centro Editorial e Didático da UFBA.

BRANDÃO, P. R. B. (2005). Geografias da presença galega na cidade da Bahia. Salvador, EDUFBA.

CAPEL, H. (1972). Agentes y estratégias em la producion del espacio urbano español. Revista Geográfica, n. 8, pp. 19-56.

CARVALHO, D. de (1935). Geographia humana, política e econômica. São Paulo, Companhia Editora Nacional.

CASTELLS, M. (1999). A sociedade em rede. São Paulo, Paz e Terra, vol. I.

CASTLES, S; MILLER, J. (2009). The age of migration. Nova York, Guilford Press.

COHEN, R. (2005). Globalização, migração internacional e cosmopolitismo quotidiano. Lisboa, ICS.

CORRÊA, R. L. (2005). O espaço urbano. São Paulo, Ática.

FAZITO, D. (2010). Análise de redes sociais e migração. Dois aspectos fundamentais do "retorno. Revista Brasileira de Ciências Sociais, v. 25, n. 72, pp. 89-100.

FORM, W. H. (1954). The place of social structure in the determination of land use: some implications for a theory of urban ecology. Social Forces, Michigan, v. 32, n. 4.

GANDON, T. R. d’A. (2010). Portugueses na Bahia na segunda metade do séc. XIX, emigração e comércio. Salvador, Eduneb.

HARVEY, D. (2005). O Novo Imperialismo. São Paulo, Loyola.

MARTINS, J. de S. (1998) O problema das migrações no limiar do terceiro milênio. In: SIMPÓSIO O FENÔMENO MIGRATÓRIO NO LIMIAR DO 3 MILÊNIO, DESAFIOS PASTORAIS. São Paulo.

MARTINS, O. (1956). Fomento rural e emigração. Lisboa, Guimarães \& Cia.

MASSEY, D. S. et al. (1993). Theories of international migration: a review and appraisal. Population and Development Review, v. 19, n. 3, pp. 431-466.

MOURAD, L. N. (2011). O processo de gentrificação do centro antigo de Salvador 2000 a 2010. Tese de doutorado. Salvador, Universidade Federal da Bahia.

NASCIMENTO, A. A. V. (1985). Dez Freguesias da cidade do Salvador. Salvador, Empresa Gráfica da Bahia.

NUSCHELER, F. (1996). "O problema das Migrações no Contexto Mundial”. In: SARMENTO, W. M.; GMÜNDER, U. (orgs.). Migrações no Brasil e no Mundo. Salvador, Goether-Institut.

OBERACKER Jr., H. C. (1985). A contribuição teuta. À formação da nação brasileira. Rio de Janeiro, Presença.

OLIVEIRA, F. de (1987). O elo Perdido, classe e identidade de classe. São Paulo, Brasiliense.

PALACIOS, M. das G. L. de S. (2009). A reforma do Pelourinho, o Período Pré-1992. Dissertação de mestrado. Belo Horizonte, Universidade Federal de Minas Gerais.

PORTES, A. (2006). Estudos sobre as migrações contemporâneas, Transnacionalismo empreendorismo e a segunda geração. Lisboa, Fim de Século.

PRIORE, M. Del; VENANCIO, R. (2013). Uma breve história do Brasil. São Paulo, Planeta. 
RAVENSTEIN, E. G. (1885). The Laws of Migration. Londres, Blackwel Publishing for the Royal Statistical Society.

(1889). The Laws of Migration. Journal of the Royal Statistical Society. Londres, v. 52, n. 2, pp. 241-305.

RIBEIRO, D. de A. (2011). Gentrification no Parque Histórico do Pelourinho, Salvador - Bahia. Dissertação de mestrado. Salvador, Universidade Federal da Bahia.

(2018a). Migrações para o Eixo Pelourinho Santo Antônio. Salvador - Bahia. Tese de doutorado. Salvador, Universidade Federal da Bahia.

(2018b). "Ensaio sobre a Arché Geográfica soteropolitana". In: GOMES, I. A. (org.). A produção do conhecimento geográfico. Ponta Grossa, Atena.

RIBEIRO, D. (1995). O povo brasileiro. A formação e o sentido do Brasil. São Paulo, Companhia das Letras.

RODRIGUES, R. N. (2010). Os africanos nos Brasil. Rio de Janeiro, Centro Edelstein de Pesquisas Sociais.

SANTOS, M. A. da S. (1977). Comércio Português na Bahia, 1870-1930. Salvador, UFBA.

(2009). Casa e balcão, os caixeiros de Salvador 1890-1930. Salvador, UFBA.

SANTOS. M. (2008a). Economia espacial. Críticas e alternativas. São Paulo, Edusp. (2008b). O centro da cidade do Salvador. Salvador, Liv. Progresso Editora.

SARMENTO, W. M. (1996). “Migrações no Brasil-teoria e realidade”. In: SARMENTO, W. M.; GMÜNDER, U. (orgs.). Migrações no Brasil e no Mundo. Salvador, Goether-Institut.

SASSEN, S. (2007). Una sociologia de la globalización. Buenos Aires, Katz.

SAYAD, A. (1998). A imigração ou os paradoxos da alteridade. São Paulo, Edusp.

SINGER, P. I.(1976). Dinâmica populacional e desenvolvimento: o papel do crescimento populacional no desenvolvimento econômico. São Paulo, Hucitec.

SMITH, N. (1996). The new urban frontiers. Gentrification and the revanchist city. Nova York, Routledge. (2006). "A gentrificação generalizada: de uma anomalia local à "regeneração" urbana como estratégia urbana global”. In: ZACHARIASEN, C. B.; NICOLAS, D. H.; ARC, H. R. d'. (orgs.). De Volta à Cidade. Dos processos de gentrificação às políticas de "revitalização" dos centros urbanos. São Paulo, Annablume.

TAVARES, L. H. D. (2008). História da Bahia. Salvador/São Paulo, Edufba/Unesp.

VASCONCELOS, P. de A. (2002). Salvador: transformações e permanências (1549-1999). Ilhéus, Editus.

(2013). "Contribuição para o debate sobre os processos e formas socioespaciais nas cidades". In: VASCONCELOS, P. A.; CORREA, R. L.; PINTAUDY, S. M. (orgs.). A cidade contemporânea, segregação espacial. São Paulo, Contexto.

(2016). Salvador: transformações e permanências (1549-1999). Salvador, EDUFBA.

VIANA FILHO, L. (1946). O negro na Bahia. São Paulo, José Olympio.

Texto recebido em 14/abr/2020

Texto aprovado em 16/jun/2020 